\title{
The Effects Analysis of Transformational Leadership, Work Motivation and Compensation on Employee Performance in PT. Sago Nauli
}

\author{
Kuras Purba $^{1}$, Kusman Sudibjo ${ }^{2}$ \\ ${ }^{1}$ Postgraduate Program in Universitas Prima Indonesia, Indonesia \\ ${ }^{2}$ Sekolah Tinggi Teologi Pelita Kebenaran Medan, Indonesia \\ kuraspurba@yahoo.co.id
}

\begin{abstract}
This study aims to describe the effect of transformational leadership, work motivation and compensation on the performance of employees of PT. Sago Nauli. This research was conducted at PT. Sago Nauli which lasts for 5 (five) months, starting from October 2019 to February 2020. This research uses proportional random sampling method. The population in this study were all employees of PT. Sago Nauli palm oil mill totaling 180 people. The respondents of this study were determined using the slovin formula which numbered 124 (one hundred twenty four) people. The instrument used was a questionnaire to collect data from transformational leadership variables, work motivation, compensation and employee performance variables. Data analysis techniques used are validity test, reliability test, descriptive analysis, multicollinearity test, normality test, heterokedasticity test, multiple linear regression analysis, partial hypothesis test or t test, simultaneous hypothesis test or F test, and calculation of the coefficient of determination. Descriptive analysis results for transformational leadership variables, work motivation, compensation variables and employee performance are in the good category at PT. Sago Nauli. Based on partial analysis, transformational leadership, work motivation, compensation has a positive and significant effect on employee performance at PT Sago Nauli. Simultaneously, transformational leadership, work motivation and compensation have a positive and significant influence on employee performance at PT. Sago Nauli. The contribution of transformational leadership variables, work motivation, and compensation explained the employee performance variable of 0.760 or $76 \%$. The remaining 0.240 or $24 \%$ is influenced by other independent variables not examined in this study.
\end{abstract}

Keywords transformational leadership, work motivation; compensation; performance

\section{Introduction}

As one of the pillars of the national economy, palm oil, which comes from oil palm plantations, does have enormous economic value. This happens because, most of the oil palm plantations are located in remote areas which have very few facilities and infrastructure. With the existence of oil palm plantations in the area, slowly but surely helped to develop the economy of the surrounding area.

Regional development carried out by oil palm plantations through various development steps, where the support of central and local governments also have a major role in granting permits for the location of oil palm plantations. Therefore, national oil palm plantations in general have a large role in regional development. 
PT. Sago Nauli is a company engaged in the field of oil palm plantations and mills located in Sinunukan II Village, Sinunukan District, Mandailing Natal District, North Sumatra Province, processing the palm fruits of local residents and their own gardens have succeeded in providing increased welfare for the surrounding population, especially in the sub-districts Sinunukan.

Development and growth of PT. Sago Nauli itself is certainly supported by the performance of its employees. Performance becomes the real foundation in an organization because if there is no performance then the goals of the organization cannot be achieved. Organizations generally believe that to achieve excellence must strive for the highest individual performance, because basically individual performance affects the performance of a team or work group and ultimately affects overall organizational performance. Performance appraisal of employees is usually based on job descriptions that have been prepared by the company. Thus, the good and bad performance of employees is seen from their ability to carry out tasks in accordance with the work that has become their responsibility.

To measure the performance of employees at PT. Sago Nauli has a performance appraisal every semester, in which semester one starts from January to June while the second semester starts from July to December. Based on the results of the assessment shows that the performance of employees at PT. Sago Nauli is still not optimal and tends to decrease.

One factor that is considered to affect employee performance is job satisfaction. Where employees who have high levels of job satisfaction will tend to have high performance as well (Ronny and Lila, 2020). Another factor that can affect employee performance is work motivation. Employees who have high work motivation will affect the performance of these employees (Ronny and Susanti, 2019). Apart from transformational leadership and work motivation, compensation is also one of the factors that can affect the level of employee performance in an organization (Ronny, 2020).

Based on the description above, the researchers conducted a research entitled "Analysis of the Effects of Transformational Leadership, Work Motivation and Compensation on Employee Performance at PT. Sago Nauli."

\section{Review of Literature}

\subsection{Transformational Leadership}

During life, humans are never separated from leadership, even the most independent modern people still need leaders (Sudibjo, 2018).

According to Robbins and Judge (2008), transformational leaders are leaders who inspire their followers to put aside their personal interests for the good of the organization and are able to have an extraordinary influence on their followers. According to Yukl (2010), transformational leadership is a situation where the followers of a transformational leader feel trust, admiration, loyalty and respect for the leader, and they are motivated to do more than they initially expected.

Leadership can be defined as a process of directing and giving influence to the activities of a group of members who are related to their duties (Stoner, 1992: 114). According to Gorton et al., Leadership is a characteristic of leaders in influencing subordinates to achieve organizational goals. The success of leadership is partly determined by the ability of leaders to develop their organizational culture. (Arif, 2019).

From some of the above understanding, it can be concluded that transformational leadership is the style of a leader who is able to influence his subordinates to improve employee performance in order to achieve organizational goals effectively and efficiently. 
The dimensions of transformational leadership according to Bass and Avolio in Sudaryono (2014) are as follows:

1. Idealized influence. Where the first is described as the behavior of leaders who make followers admire, respect and trust at the same time.

2. Inspirational motivation. In this dimension, transformational leaders are described as leaders who are able to articulate clear expectations of the achievements of subordinates, demonstrating their commitment to all objectives

3. Organization, and able to arouse team spirit in the organization through growing enthusiasm and optimism.

4. Intlectual stimulation. Transformational leaders must be able to foster new ideas, provide creative solutions to the problems faced by subordinates, and provide motivation to subordinates to look for new approaches in carrying out organizational tasks.

5. Individualized consideration. In this dimension, the transformational leader is described as a leader who is willing to listen attentively to the input of subordinates specifically wanting to pay attention to the needs of subordinates for career development.

\subsection{Work Motivation}

Motivation comes from the Latin word movere which means drive or driving force. Motivation in management is only aimed at human resources in general and in particular subordinates.

According to Mangkunegara (2005), motivation is a process that plays a role in the intensity, direction, and duration of individual efforts towards achieving goals.

According to Hasibuan (2007), motivation is the provision of a driving force that creates the excitement of one's work, so that they want to work together, work effectively and be integrated with all their efforts to achieve satisfaction.

According to Handoko (2012), motivation is a condition in a person that drives an individual's desire to carry out certain activities in order to achieve goals. So the motivation that is in someone is the driving force that will manifest a behavior in order to achieve the goal of self satisfaction.

Based on the opinions of the experts above, the researcher concludes that motivation is something in a person who pushes himself to meet his needs in achieving satisfaction according to his goals. Motivation is a condition that moves a person who is directed to achieve organizational goals.

According to Hasibuan (2008), employee motivation is influenced by physical needs, the need for security and safety, social needs, the need for self-esteem, and the need for selfactualization. Then from the needs factor is reduced to dimensions employee work motivation, namely:

1. Physiological or physical needs, shown by giving bonuses, food allowances, transportation fees, and so forth.

2. Security, indicated by occupational safety and safety facilities which include such as labor social security, pension funds, health benefits, health insurance, and work safety equipment.

3. Social, shown by interacting with others, including by establishing harmonious working relationships, the need to be accepted in groups and the need to love and be loved.

4. Award, shown by recognition and appreciation based on ability, namely the need to be respected and valued by other employees and leaders towards their work performance.

5. Self-actualization, shown by the nature of work that is interesting and challenging, where the employee will mobilize his skills, abilities, skills, and its potential. In meeting this need can be done by companies by organizing education and training. 


\subsection{Compensation}

According to Handoko (2012), compensation reflects the size of their work among the employees themselves, their families and the community.

According to Hasibuan (2005), compensation is all income in the form of money, direct or indirect goods received by employees in return for services provided to the company. Explanation of compensation in the form of money is that employees are paid with a sum of money, while compensation in the form of goods is compensation that is paid with goods to their employees.

According to Milkovich and Newman (2008), compensation relates to all forms of financial rewards and tangible services, as well as benefits received by employees as part of a work relationship.

Based on the opinions of the experts above, the researcher concludes that compensation is a reward for the services provided by the company or organization to its employees because it has performed its obligations by fulfilling all its duties.

According to Michael and Harold in Pantja Djati (2003), compensation assessment indicators are divided into three forms, namely:

1. Material compensation

Material compensation is compensation that is not only in the form of money, such as salaries, bonuses and commissions, but all forms of physical reinforcements, such as parking facilities, telephones, and comfortable office space and various forms of benefits such as pensions, health insurance.

2. Social compensation

Social compensation is related to the need to interact with others. This form of compensation includes status, recognition as an expert in their field, appreciation for achievement, promotion, tenure certainty, recreation, the formation of decision-making groups, and special groups formed to solve company problems.

3. Activity compensation

Activity compensation is compensation that is able to compensate for aspects of work that are disliked by employees by providing opportunities to carry out certain activities. The form of activity compensation can be in the form of power, delegation of authority, responsibility, participation in decision making, and training.

\subsection{The Performance}

The term performance or work performance comes from the English word "performance". According to Khan in Busro (2018), performance is defined as work ability in terms of quality and quantity. Performance is a work performance (performance) both in quantity and quality achieved by someone during a certain period, usually within one year.

According to Ivancevich, Konopaske and Matteson (Busro, 2018) that performance shows the ability and skills of workers. Opinions emphasize the competence of human resources possessed by organizations, ranging from the ability of employees' cognition, affection, and psychomotor.

According to Kaswan (2012), there are six criteria that are used as a basis for assessing performance, including:

1. Quality.

How far / well the process or outcome of carrying out an activity approaches perfection, in terms of conformity with the ideal way of carrying out an activity or meeting the desired objectives of an activity. 
2. Quantity.

The amount produced is expressed in terms of dollars / rupiah, the number of units, or the number of activity cycles that have been completed.

3. Timeliness.

How far / whether an activity is completed, or the results produced, at the earliest time desired from the point of view of coordinating with other outputs or maximizing the time available for other activities.

4. Cost effectiveness.

To what extent / good organizational resources (eg human, monetary, technological, material) are maximized in terms of obtaining the highest profit or reduction in losses from each unit, or examples of resource use.

5. The need for supervision.

To what extent / is an employee able to carry out work functions without having to ask for supervisory assistance or require supervision intervention to prevent adverse results.

\subsection{Framework}

a. The Effect of Transformational Leadership on Employee Performance

According to Siagian (2003), it can be said that the quality of leadership contained in an organization plays a very dominant role in the success of the organization in carrying out its various activities, especially seen in the performance of its employees According to Robbins (2010), if a leader succeeds in influencing subordinates with his vision, instilling his charisma, motivating and being an inspiration, stimulating intellectual, creativity and respecting his employees can be sure that employees will work well, seriously and loyal to the company so that their performance increases.

\section{b. Effect of Work Motivation on Employee Performance}

According to Samsudin (2005), it is stated that motivation as a process of influencing or encouraging from the outside towards a person or working group so that they want to carry out something that has been determined. Motivation can also be interpreted as a natural urge to satisfy and sustain life.

According to Aries and Ghozali (2006), motivation is the giving of individual impulses to act that cause the person to behave in a certain way that leads to the goal. Motivation is one of the goals so that employees who are given motivation can work in accordance with work references and responsibilities given so that company goals can be achieved properly.

\section{c. Effect of Compensation on Employee Performance}

Compensation is one way companies can provide in the form of rewards to employees. Compensation can increase or decrease employee performance. Providing compensation to employees needs to get more attention by the company. Compensation must have a strong, correct and fair basis.

According to Hasibuan in Kadarisman (2012), the purpose of providing compensation (compensation) is "as a bond of cooperation, job satisfaction, effective procurement, motivation, employee stability, discipline and the influence of trade unions and government".

With a good compensation in the company will bring a positive impact on the company. If the employee gets compensation in accordance with what has been done in the company, then the employee will tend to do the best for the company 


\subsection{Hypothesis}

Based on the theory and frame of mind mentioned above, the hypotheses in this study are:

1. Transformational leadership has a positive and significant impact on the performance of employees of PT. Sago Nauli.

2. Work motivation has a positive and significant effect on the performance of employees of PT. Sago Nauli.

3. Compensation has a positive and significant effect on the performance of the employees of PT. Sago Nauli.

4. Transformational leadership, work motivation, and compensation have a positive and significant effect on the performance of employees of PT. Sago Nauli.

\section{Research Methods}

This research was conducted at the palm oil mill of PT. Sago Nauli having his address at Sinunukan II Village, Kecamanatan Sinunukan, Mandailing Natal Regency, North Sumatra.

This type of research is a survey research with associative quantitative research methods. According to Sugiyono (2014) the definition of associative quantitative research methods is research that aims to determine the effect or also the relationship between two or more variables.

In this study, associative research methods are used to determine the magnitude of influence between one variable with another variable. The population in this study were all employees at PT. Sago Nauli in 2020 as many as 180 employees. Samples were taken based on the probability sampling technique that is proportionate random sampling using the Slovin formula so that a total sample of 124 employees was obtained.

The research model is as follows:

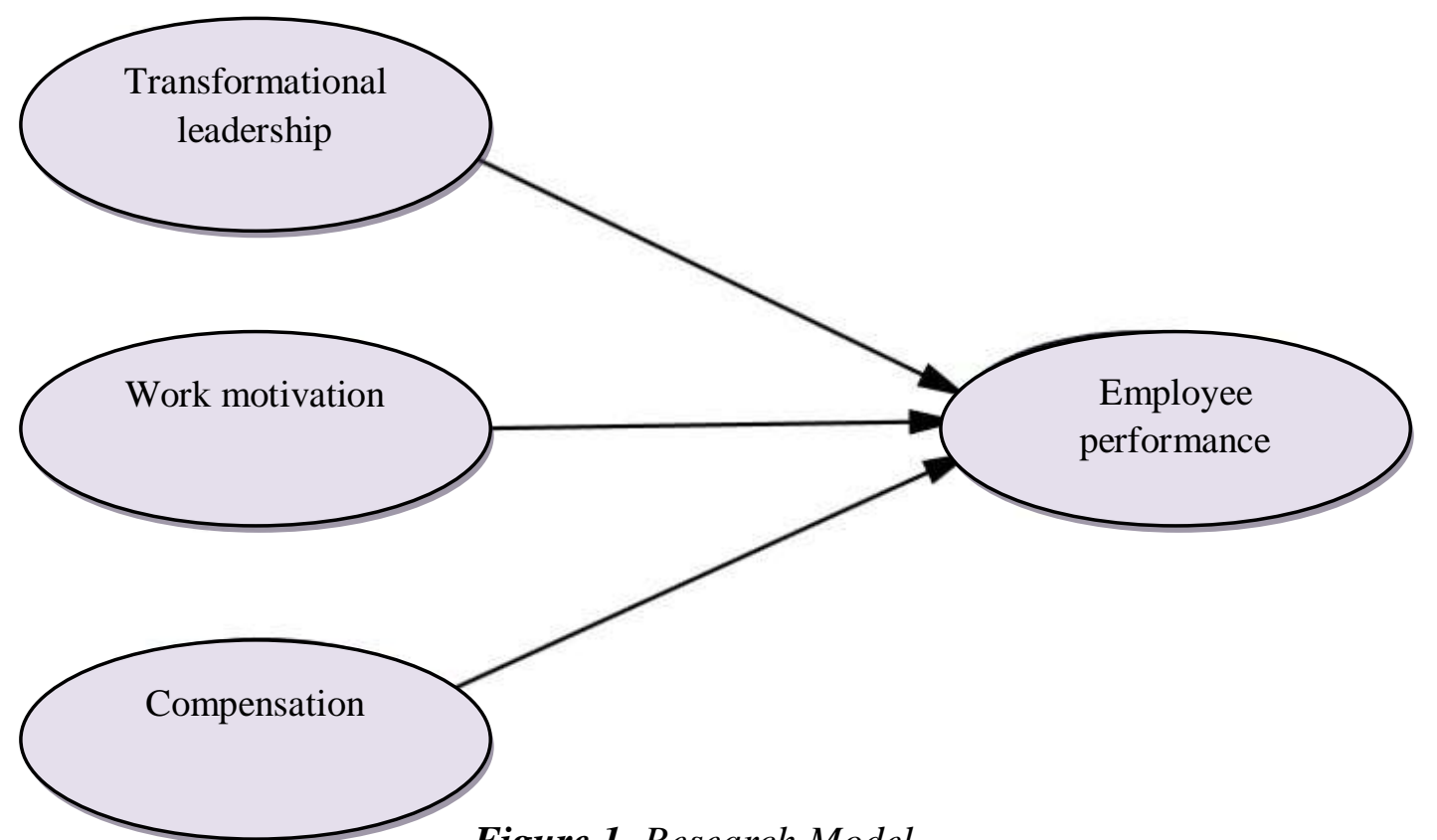

Figure 1. Research Model 
The study was conducted at a particular time (cross sectional) that reflects the phenomenon of a situation at a time in 2020. The measurement scale of the variable used in this study is a Likert scale. To test the model and hypothesis used multiple linear regression analysis, this study uses SPSS version 24, and hypothesis testing is done through t test and F test.

\section{Discussion}

PT. Sago Nauli was founded in 1995 located in Sinunukan II Village, Sinunukan SubDistrict, Mandailing Natal District, North Sumatra. It has a palm oil factory with a capacity of 60 tons / hour which processes fresh fruit bunches into crude palm oil (CPO). PT Sago Nauli is a company that actively fosters the community of oil palm farmers in Sinunukan Village which is incorporated in the village unit cooperative (KUD) so that the processed fresh fruit bunches are the fruit of the surrounding community. Thus the existence of PT. Sago Nauli has an impact on economic growth and community welfare in Sinunukan Village.

The results of the descriptive statistical analysis were performed on each research variable, namely transformational leadership, work motivation, compensation and employee performance. Descriptive statistical analysis provided is a description of ponden answers namely PT. Sago Nauli while the results of the descriptive statistical analysis show that in general transformational leadership is in good condition with a mean value of 3.51 (scale 1 to 5 ), work motivation is sufficient with a mean value of 3.17 (scale of 1 to 5), compensation in an adequate state with a mean value of 3.29 (a scale of 1 to 5) and an employee's performance in a sufficient state with a mean value of 3.15 (a scale of 1 to 5).

Before testing hypotheses using the $\mathrm{t}$ test and $\mathrm{F}$ test, a classic assumption test consists of a normality test, a multicollinearity test and a hesteroscedasticity test.

The results of the classic assumption test are as follows:

\subsection{Nominality Test}

Normality test with the One Kolmogrov Smirnov method according to Priyatno (2014), the test criteria are:

1. If the significance value $>0.05$, then the data are normally distributed.

2. If the significance value $<0.05$, then the data are not normally distributed.

Table 1. Normality Test Table

One-Sample Kolmogorov-Smirnov Test

\begin{tabular}{|c|c|c|}
\hline \multirow{2}{*}{\multicolumn{2}{|c|}{ Un }} & lardized Resid \\
\hline & & \multirow{2}{*}{$\begin{array}{r}124 \\
.0000000 \\
\end{array}$} \\
\hline \multirow[t]{2}{*}{ Normal Parameters $\mathrm{a}, \mathrm{b}$} & Mean & \\
\hline & Std. Deviation & 1.50684740 \\
\hline \multirow{3}{*}{$\begin{array}{l}\text { Most Extreme } \\
\text { Differences }\end{array}$} & Absolute & .069 \\
\hline & Positive & .047 \\
\hline & Negative & -.069 \\
\hline Test Statistic & & .069 \\
\hline Asymp. Sig. (2-tailed) & & $.200^{\mathrm{c}, \mathrm{d}}$ \\
\hline
\end{tabular}

a. Test distribution is Normal.

b. Calculated from data. 
c. Lilliefors Significance Correction.

d. This is a lower bound of the true significance.

The table above shows that the Asymp value. Sig is 0.200 , this value indicates that the value is greater than 0.05 , so it can be concluded that the data meets the requirements of normally distributed residual data.

\subsection{Multicollinearity Test}

Multicollinearity can also be seen from (1) the value of tolerance and its opponents (2) variance inflation factor (VIF). Tolerence measures the variability of selected independent variables that are not explained by other independent variables. So a low tolerance value equals a high VIF value (because VIF $=1$ / Tolerance). The cut-off value commonly used to indicate the presence of multicollinearity is a Tolerance value of less than 0.10 or equal to a VIF value greater than 10 (Ghozali, 2016).

Table 2. Table of Multicollinearity Tests

\begin{tabular}{|c|c|c|c|c|c|c|c|c|}
\hline \multirow[b]{2}{*}{ Model } & & \multicolumn{2}{|c|}{ Unstandardized Coefficients } & \multirow{2}{*}{$\begin{array}{c}\text { Standardized } \\
\text { Coefficients } \\
\text { Beta }\end{array}$} & \multirow[t]{2}{*}{0} & \multirow[b]{2}{*}{ Sig. } & \multirow{2}{*}{$\begin{array}{l}\text { Collinearity } \\
\text { Tolerance }\end{array}$} & \multirow{2}{*}{$\begin{array}{c}\text { Statistics } \\
\text { VIF }\end{array}$} \\
\hline & & B & Std. Error & & & & & \\
\hline 1 & (Constant) & -3.344 & 1.367 & & -2.446 & .016 & & \\
\hline & $\mathrm{X} 1$ & .556 & .058 & .535 & 9.549 & .000 & .623 & 1.606 \\
\hline & $\mathrm{X} 2$ & .148 & .048 & .194 & 3.104 & .002 & .502 & 1.992 \\
\hline
\end{tabular}

a.Dependent Variable: $Y$

The results of multicollinearity testing can be seen that the VIF value and tolerance are as follows: The transformational leadership variable has a VIF value of 1,606 and tolerance of 0.623 . Work motivation variable has a VIF value of 1,992 and tolerance of 0.502 . The compensation variable has a VIF value of 1,683 and a tolerance of 0.594 . From these provisions that if the VIF value $<10$ and tolerance $>0.10$ then there is no symptom of multicollinearity and the values obtained from the calculation are in accordance with the provisions of the VIF value and tolerance, then it can be concluded that between the independent variables there is no multicollinearity.

\subsection{Heteroscedasticity Test}

According to Ghozali (2016), the heteroscedasticity test aims to test whether in the model there is an inequality of variables from the residuals of one observation to another. A good regression model is not heteroscedasticity

Table 3. Hesteroscedasticity Test Table

\begin{tabular}{|c|c|c|c|c|c|c|}
\hline \multirow[b]{2}{*}{ Model } & & \multicolumn{2}{|c|}{ Unstandardized Coefficients } & \multirow{2}{*}{$\begin{array}{c}\text { Standardized } \\
\text { Coefficients } \\
\text { Beta }\end{array}$} & \multirow[b]{2}{*}{$\mathrm{t}$} & \multirow[b]{2}{*}{ Sig. } \\
\hline & & B & Std. Error & & & \\
\hline \multirow[t]{4}{*}{1} & (Constant) & 2.582 & .754 & & 3.425 & .001 \\
\hline & $\mathrm{X} 1$ & -.007 & .032 & -.024 & -.217 & .828 \\
\hline & $\mathrm{X} 2$ & -.043 & .026 & -.206 & -1.650 & .102 \\
\hline & X3 & -.007 & .026 & -.032 & -.276 & .783 \\
\hline
\end{tabular}


The visible results show that the parameter coefficient for the independent variable is not significant, namely the transformational leadership variable $0.828>\alpha=0.05$; variable work motivation $0.102>\alpha=0.05$; compensation variable $0.783>\alpha=0.05$; it can be concluded that the regression model does not contain heteroscedasticity.

Based on the results of data processing that has been done, it can be seen that the relationship model from multiple linear regression analysis is seen from the following table:

Table 4. Multiple Linear Regression

\begin{tabular}{|c|c|c|c|c|c|c|}
\hline \multirow[b]{2}{*}{ Model } & & \multicolumn{2}{|c|}{ Unstandardized Coefficients } & \multirow{2}{*}{$\begin{array}{c}\text { Standardized } \\
\text { Coefficients } \\
\text { Beta }\end{array}$} & \multirow[b]{2}{*}{$\mathrm{t}$} & \multirow[b]{2}{*}{ Sig. } \\
\hline & & B & Std. Error & & & \\
\hline 1 & (Constant) & -3.344 & 1.367 & & -2.446 & .016 \\
\hline & $\mathrm{X} 1$ & .556 & .058 & .535 & 9.549 & .000 \\
\hline & $\mathrm{X} 2$ & .148 & .048 & .194 & 3.104 & .002 \\
\hline & X3 & .246 & .047 & .301 & 5.245 & .000 \\
\hline
\end{tabular}

The equations of multiple linear regression analysis in this study are as follows:

Performance $=-3,344+0,556$ Transformational Leadership $+0,148$ Work Motivation $+0,246$ Compensation.

Based on the above equation, it can be seen that the value of component a or constant is - 3,344, the value of component b1 or the regression coefficient for transformational leadership variables is 0.556 , indicating that the transformational leadership variable has a positive influence on employee performance, which means the higher the transformational leadership, the employee's performance will be increasingly increase and conversely the lower the transformational leadership, the employee's performance will decrease.

The component value b2 or the regression coefficient for work motivation variable of 0.148 indicates that the work motivation variable has a positive effect on employee performance variables, which means the higher the work motivation, the employee's performance will increase and conversely the lower the work motivation, the employee's performance will be increasingly decreased.

The component value b3 or the regression coefficient for the compensation variable is 0.246 , indicating that the compensation variable has a positive effect on the employee performance variable, which means the higher the compensation, the employee's performance will increase and conversely the lower the compensation, the employee's performance will decrease.

The significance value in multiple linear regression analysis shows that the value of $p$ value Sig or the significance value of the influence between transformational leadership variables on employee performance is 0,000 where the value of $\mathrm{p}$ value Sig or the resulting significance value is $<0.05$, it can be concluded that the regression the influence between transformational leadership variables on employee performance variables in this study was significant.

The value of $p$ value Sig or the significance value of the influence between the variables of work motivation on employee performance is 0.002 where the value of $p$ value Sig or the resulting significance value is $<0.05$, it can be concluded that the regression effect between the variables of work motivation on employee performance variables in this research is significant, while the value of $\mathrm{p}$ value $\mathrm{Sig}$ or the significance value of the influence between compensation variables on employee performance is 0,000 where the value of $p$ value Sig or the resulting significance value is $<0.05$, it can be concluded that the regression 
of the influence between the compensation variables on the variable Employee performance in this study was significant.

Table 5. Coefficient of Determination

\begin{tabular}{ll|r|r|r} 
& \multicolumn{4}{c}{ Table 5. Coefficient of Determination } \\
Model & R & R Square & \multicolumn{1}{c}{$\begin{array}{c}\text { Adjusted R } \\
\text { Square }\end{array}$} & $\begin{array}{c}\text { Std. Error of the } \\
\text { Estimate }\end{array}$ \\
\hline 1 & $.875^{\mathrm{a}}$ & .766 & .760 & 1.526 \\
\hline
\end{tabular}

The results of the calculation of the coefficient of determination (R Square) from IBM SPSS Statistics 24.0 for contributions between transformational leadership variables, work motivation, and compensation to employee performance variables are 0.760 or $76 \%$. This shows that the contribution of transformational leadership variables, work motivation, and compensation to improve employee performance variables is 0.760 or $76 \%$, while the remaining 0.240 or $24 \%$ is influenced by other variables not examined in this study.

\section{Conclusion}

1. Descriptive analysis results for transformational leadership variables, work motivation, compensation and employee performance at PT. Sago Nauli is in the good category.

2. Partial hypothesis test results or $t$ test, for transformational leadership variables on employee performance at PT. Sago Nauli is a sig value $<0.05$ which means that transformational leadership has a positive and significant impact on employee performance at PT. Sago Nauli.

3. Partial hypothesis test results or $\mathrm{t}$ test, for the variable work motivation on employee performance at PT. Sago Nauli is a sig value $<0.05$ which means that work motivation has a positive and significant effect on employee performance at PT. Sago Nauli.

4. Partial hypothesis test results or $t$ test, for the variable compensation for employee performance at PT. Sago Nauli is a sig value $<0.05$ which means that compensation has a positive and significant impact on employee performance at PT. Sago Nauli.

5. Based on the results of the simultaneous hypothesis test or F test for the influence between transformational leadership, work motivation and compensation on employee performance with a value of sig $<0.05$, meaning that transformational leadership, work motivation and compensation have a positive and significant effect on employee performance in PT. Sago Nauli. The contribution of transformational leadership variables, work motivation and compensation to improve employee performance is 0.760 or $76 \%$, while the remaining 0.240 or $24 \%$ is influenced by other variables not examined in this study.

\section{Suggestion}

1. To improve the effectiveness of the application of transformational leadership, given that transformational leadership has a positive and significant effect on employee performance, it will be very necessary for leaders with leadership styles that become role models or role models for each employee, have integrity, have a good attitude, and discipline in work. By coordinating actions to form team work

2. solid, interaction with subordinates is able to create the concept of partnership for each employee and will create a good behavior for employees such as mutual respect between employees. And the need to maintain the attitude of leaders who are eager and willing to listen to the ideas / ideas of employees will be an important foundation for the sustainability of the company's organization continuously. 
3. To increase work motivation; management of PT. Sago Nauli better understands the needs of each member in accordance with the conditions and situation of each - each so that they are able to design work programs that can motivate employees to work more optimally for example for employees who have security needs, the company can provide employment and insurance social security, for employees who have social needs, companies can design outbound events or outting together with employees.

4. For compensation, the Company must be fair and balanced in providing compensation to employees according to the level of work. Compensation in the form of salary given by the company still follows the applicable regulations and in accordance with the level of work performance. Providing incentives for achieving work targets must be maintained so that employees are motivated to work better

5. For further researchers it is recommended to conduct research using other independent variables that have not been examined in this study, such as training, communication and organizational culture.

\section{References}

Arif, S. (2019). Influence of Leadership, Organizational Culture, Work Motivation, and Job Satisfaction of Performance Principles of Senior High School in Medan City. Budapest International Research and Critics Institute-Journal (BIRCI-Journal). P. 239-254

Busro, Muhammad. (2018). Teori-Teori Manajemen Sumber Daya Manusia. Jakarta: Prenadamedia Group.

Djati, S. Pantja dan M. Khusaini. (2003). Kajian terhadap kepuasan kompensasi, komitmen organisasi, dan prestasi kerja. Jurnal Manajemen dan Kewirausahaan, 5(1), 25-41

Ghozali, Imam. (2016). Aplikasi Analisis Multivariete Dengan Program IBM SPSS 23 (Edisi 8).Cetakan ke VIII. Semarang: Badan Penerbit Universitas Diponegoro.

Hasibuan, Malayu SP. (2005). Manajemen Sumber Daya Manusia Edisi Revisi. Jakarta: PT Bumi Aksara

Hasibuan, Malayu S.P. (2007). Manajemen Sumber Daya Manusia Perusahaan. Bandung: PT. Bumi Aksa.

Hasibuan, Malayu SP. (2008). Manajemen Dasar, Pengertian, Dan Masalah. Jakarta: PT Bumi Aksara

Handoko, T. Hani. (2012). Manajemen Personalia dan Sumber Daya Manusia. Yogyakarta: BPFE Kadarisman, M. 2012. Manajemen Kompensasi. Jakarta: Rajawali Pers.

Kaswan. (2012). Manajemen Sumber Daya Manusia untuk Keunggulan Bersaing Organisasi. Yogyakarta: Graha Ilmu.

Mangkunegara. (2005). Motivasi Kinerja. Jakarta: Gramedia Widisarana Indonesia. Milkovich, George and Jerry Newman. 2008. Compensation. Ninth Edtion. USA

Priyatno, Duwi. (2014). SPSS 22 Pengolah Data Terpraktis. Andi. Yogyakarta

Robbins, S.P., \& Judge, T.A. (2008). Perilaku Organisasi. Edisi Kedua belas. Jakarta: Salemba Empat

Ronny, Yusuf Edward. (2020). Manajemen Sumber Daya Manusia Sebuah Pengantar. Medan: Gerhana Media Kreasi

Ronny, Yusuf Edward \& Lila Maria Kaban. (2020). The Effect of Transformational Leadership and Competence on Employee Performance with Job Satisfaction as Intervening Variable.Academic Journal of Economic Studies. Vol. 6, No. 2, pp. 62-72. 
Ronny, Yusuf Edward \& Susanti. (2019). The Effect of Organizational Culture and Work Motivation on Employee Performance with Job Satisfaction as an Intervening Variable at PT. Berkat Bima Sentana. IOSR Journal of Business and Management. Vol 21, No. 3, pp. 31- 38 .

Samsudin. (2005). Manajemen Sumber Daya Manusia. Bandung Pustaka Setia. Sugiyono. 2014. Metode Penelitian Manajemen. Yogyakarta: Alfabeta.

Sudibjo, Kusman. (2018). Theopreneruical Leadership. Medan: Pelita Kebenaran Press

Sudaryono. (2014). Budaya dan Perilaku Organisasi. Jakarta: Lentera Ilmu Cendekia Yukl, Gary. (2010). Kepemimpinan Dalam Organisasi. Edisi Kelima. Jakarta: PT Indeks 